\title{
THE STATE UNIVERSITY OF IOWA AND THE CIVIL WAR
}

By HARRISON JOHN THORNTON ${ }^{1}$

Like its sister institutions, the State University of Iowa felt the impact of the civil strife that rent the nation in the middle of the nineteenth century. Ellen A. Moore, who was enrolled during the war years, later wrote: "The shot fired at Sumter was heard upon the University campus. Its reverberations resounded through the old stone building and awakened from silent meditation the students of Euclid and Horace." It was just seven months after reopening that "the call of fife and drum" was heard, and from the front portico of Old Capitol a line of volunteers began to move "toward the tented field."

Even before disputation had yielded to the clash of arms, heated objections to the course of southern conduct were heard upon the campus. At the closing exercises of the first year of academic operations-in June, 1856for example, a forthright denunciation was made by one of the students. The ladies of the class were required to read an essay, the gentlemen to make a declamation, and what Jeremiah Murphey had to say greatly pleased the Daily Reporter of Iowa City. Normally, the editor did not approve of the political note on such occasions, "but when our enemies contend that all parties are extinguished, and that the issue is . . . between Freedom and Slavery ... Nationalism and Sectionalism, we can but admire the sound conservatism and patriotic tone of a production like Mr. Murphey's." It would be gratifying to be able to read this essay, but students' written exercises seldom survive the ravages of the years. There can be no doubt of its tenor, however, or of the fact that it met with general acceptance. "He was frequently applauded," wrote the editor, "and he did himself and his country honor in his advocacy of true Union principles."

1Professor of History at the State University of Iowa. 198 
As soon as the news of the loss of Fort Sumter reached Iowa City, excited throngs gathered on the streets to discuss "the merits and demerits of the policy of the administration." The University City, wrote the local editor, blossomed and bloomed with the patriotic colors. "From every store and shop, from every bank and school, from every hamlet and hearthstone, from fane and ancient capitol dome, is heard the rustling minstrelsy of the flag of the stars. A thousand banners all the city over salute the early morn, and evening's twilight comes, its murkiness dispelled and irradiated by the gleam of a thousand thousand stars. Hail the glorious ensign of the free!" Large and fervent meetings were held on the courthouse grounds and at the corner of Clinton and Washington streets. The stile that crossed the campus fence at the latter point served as a platform for the speakers who addressed the crowd.

During the afternoon of April 20,1861, there was an immense gathering at this junction, or University Square as it was called. The "Washington Guards" and the "German Artillery" were present in full uniform, and thirty-four rounds were fired in honor of the Union. Addreses were made by Gov. Samuel J. Kirkwood, Mayor George W. Clark, and others. "The prevailing sentiment was that party politics should be forgotten and the great cause of the Union should prevail." All seemed animated with one purpose, the press reported-"to defend the Government and maintain the law. The evident tone of the meeting was to give no quarter to traitors north or south. It was a grand meeting and cheered every Patriot's heart. Persons volunteered themselves, their lands, their stocks, their money, their all to the sacred cause of country. Tears flowed down many a manly cheek as the different speakers depicted in truthful character the peril of liberty-and in their inmost souls, we doubt not, many not only renewed the solemn oath of fealty, but swore to avenge the insults and wrongs sought to be committed against that country to which we owe our earthly all." 


\section{The Hour OF Decision}

Charles M. Howe, who was enrolled in the University during the war years, preserved in his diary the course of his own thinking and the mood of his fellows. "I have decided . . . to go," he wrote, "as duty seems strongest in that direction. I found great excitement existing among the students, many feeling as I did on the subject. At the war meeting forty-five of our number signed their decisions in favor of going. The professors encourage the movement as much as they can under the circumstances. Our numbers increase slowly with war meetings held each day in the chapel. Marked enthusiasm prevails among the students of both sexes. The school is very unsettled and but little studying is done at present." There was much military maneuvering on the campus. "Night after night students met for war exercises in the old Athenaeum which stood at the corner of Clinton and Market streets, drawn there by a stern sense of the grave danger which threatened the nation."

Company B of the First Iowa regiment was quickly formed, and while the volunteers drilled and marched, and went into bivouac at the fair grounds, the ladies of the community set about making uniforms out of "gray satinet" material, brought from Chicago by Sen. Ezekiel Clark. Sewing machines of early crude design were pressed into operation. The stitching proved to be unreliable and many of the garments were precariously held together as "some of the soldiers soon ascertained . . . to their dismay." Young ladies of the University readily joined with the town women to "scrape lint, prepare bandages, tie comforters, assist in soliciting donations and in conducting public entertainments for the purpose of raising funds."

Both University and town men were in this first company to be assembled and leave for the field of action. On Sunday, May 5, the unit attended the Methodist church and listened to a sermon by Prof. O. M. Spencer, D.D., and the following day, under the command of Cap- 
tain Mahana, entrained for Davenport. A newspaper reporter who was present described the journey. He found "the boys" in "first rate spirits," and "rightly impressed with the patriotic duty confided to their hearts and muskets." They were "cheered to the echo as the engine whistled its departure." Indeed, joy and fervor were manifest all along the way. Crowds of citizens assembled at Downey, West Liberty, Attalisa, Wilton Junction, and at the crossroads to "cheer on the brave patriots." "Kerchiefs and bonnets . . . lifted from many a fair face, attested the universal welcome and imparted blessing." The soldiers in turn "cheered the plowman in the furrow, and the axeman by the forest oak was not forgotten. . . . At the Junction, the Wilton Brass Band played 'Yankee Doodle' and 'Hail Columbia' with fine effect, and the train responded with three rousing cheers." A great throng of people welcomed the arrival of the "Iowa City Boys" at Davenport. Enthusiasm was unbounded. "Huzzas upon huzzas made the very welkin ring." Indeed, the young warriors "felt so good" in these opening months of the war that, according to the excited reporter, they "could take the rattle-snake Confederacy for breakfast, John Bull for dinner, and the Emperor of all the Russias for supper."

\section{UNIVERSITY MEN IN MANY REGIMENTS}

This vanguard of citizen soldiery from the campus and University city was followed by many other contingents. Indeed, "there were few, if any, Iowa regiments, except the Graybeards, (composed of men over forty-five years of age) which did not contain some representatives from the University or men who later became connected with it." Probably more of the institution's personnel enlisted in the Forty-Fourth Iowa regiment than in any other. In response to Governor Stone's stirring call for short-term volunteers, Company $\mathrm{D}$ was formed on the campus, on May 2, 1864, by Professors Calver and Charles E. Borland. Eighteen days later, augmented by contingents from Cornell and Western colleges, the company left for Davenport under the command of Captain 
Borland, bearing the "beautiful flag of the finest silk" that had been presented by the women of the University at a solemn gathering in the chapel. The admiring ladies accompanied the soldiers to the railroad station to speed them on their way with smiles, tears, and prayers. Charles IM. Howe, a member of the departing company, recorded gratefully that "the ladies of our school and city had again prepared for the wants of the physical system (and) we ... partook of their hospitality before ... our final departure. Hundreds of ladies and gentlemen came forward to greet and to pay the last respects-bestowing upon us their most kind wishes for our welfare and safe return." At Davenport, Captain Borland was given "an elegant sword" by his faculty associates.

Like the first enlistments in 1861, these last of 1864 were for one hundred days. It was realized that the period was brief. "We should prefer six months men, so as to cover the whole season of military operations," declared the local editor, but he interpreted the circumstances as meaning that "General Grant and the administration expect decisive results within that time." The moment had indeed come for the final effort, for impatience with the protracted struggle was developing. "Let us end this war," the editorial went on. "We have had it on hand long enough. Our national debt is large enough. Our paper is depreciated enough for convenience. Our finances are sufficiently mixed. We should put forth one mighty effort and end the contest." Some of these men were quite aware of the inadequacy of their short period of service and they reenlisted on the expiration of the hundred days. Others held to the terms of the contract and were mustered out at Davenport.

The slender records that have survived make it difficult to determine with precision the number of University men entering the armed services for the defense of the Union. According to Pres. J. L. Pickard's computation, nearly all the male students of suitable age had left for 
the struggle before the end of the first year. The conflict "continued its demands upon the patriotic young men, and the army list made up at the close of the war contains one hundred and twenty-four names of students upon its Honor Roll." In view of the fact that the total enrollment in the University was 172 in 1860-61, the first year of the re-opening ${ }^{2}$, and 288 in 1862-63, the percentage of enlistments was distinctly impressive. Not inaptly was the University referred to in those days as "almost a female institution." The few men remaining, the local press reported, looked "lonesome and disconsolate." Two reasons prevented their departure: refusal of parental permission, and the critical stage of their studies. It was hoped that the young ladies would bear these considerations in mind, treat the disappointed youths with kindness, and "console them all they can."

At least three soldiers from the University lost their lives during the Civil war. These were Israel M. Ritter, George A. Remley, and Samuel Kirkwood Clark. Two years after the close of the conflict, Capt. Charles E. Borland, then giving instruction in physical education, died "from a disease contracted during the war." The same sad fact is to recorded of others, also. The wounds of battle were visible on the campus in the years following the struggle between North and South. Ellen Moore Rich declared that seven one-armed men were in classes she attended during the winter of 1865-66.

\section{LINCOLN'S TRIBUTE TO VOLUNTEERS}

Among the tributes paid to the student soldiers was one from the President of the United States. It was specifically addressed to the hundred-day volunteers, but, obviously, embraced in its appreciation all who served:

The term of one hundred days, for which volunteers from the states of Indiana, Illinois, Iowa and Wisconsin, volunteered under the last call of the respective governors in the months of May and June, to aid in the recent campaign of General Sherman, having expired, the President directs an official acknowledgment of their patriotic services. It was their good fortune to render efficient

\footnotetext{
2The University had been closed from 1858 to 1860 .
} 
service in the brilliant operations in the southwest and to contribute to the victories of the National arms over the rebel forces in Georgia under command of Johnston and Hood. On all occasions and in every service to which they were assigned, their duty as patriotic volunteers was performed with alacrity and courage, for which they are entitled to, and are hereby tendered, the National thanks through the governors of their respective states.

The Secretary of War is directed to transmit a copy of this order to the governors of Indiana, Illinois, Iowa and Wisconsin, and to cause a certificate of their honorable services to be delivered to the officers and soldiers of the states above mentioned, who recently served in the military force of the United States as volunteers for one hundred days.

ABRAHAM LiNCOLN

\section{Disloyalty ON THE CAMPUS}

In sharp contrast with the fervent patriotism of the University family during the tumultuous years of civil strife, a minor strain of disloyalty was present on the campus. Certain young men were avowed sympathizers with the Southern cause, and some of these became members of the University's first permanent literary societythe Zetagathians, organized in 1861. Their aggressiveness extended to the society's weekly meetings, and many were the bitter dissensions that developed. The difficulty was complicatd by the intrusion of "a brilliant young man who was not a student in the University," and he contributed vigorously to the acrimonious discussions. This proved to be too much for the loyal element to endure, and the reclacitrants were expelled from the society "for various offences."

Undeterred, the "Copperheads" promptly formed a literary society of their own: the Ciceronians, but the Zetagathians refused to recognize or debate with them. Beset by popular disapproval and opposition, this troublesome group was short-lived. The Zetagathians were pleased to record that "before another year had passed the Ciceronians ceased to exist as a society."

Another literary group to come into being during the war years-Irving Institute-minced no words in attack- 
ing disloyalists. Early in its proceedings Irving passed the following resolution: "We are most bitterly opposed to the vile and fiendish designs of the 'Copperheads' of the North who by undermining intrigues are endeavoring to promote the fiendish, hell-stricken designs of the South; . . . we will ever be found the ardent advocates of those in whose hearts the pure and unsullied fires of patriotism continue to burn, and ... . we will send forth an undying, unceasing stream . . . of withering sarcasm and stern rebuke against all those who by word or deed shall in the least favor this ungodlike rebellion."

One southern sympathizer defiantly continued to wear a copperhead emblem, in spite of its prohibition by University regulation. Even "after a patient hearing and a quiet friendly expostulation on the part of the faculty he still persistently declared that he would not obey the resolution." Angered by this example of "setting at naught the government of the University," the faculty resolved that the student in question "be and hereby is dismissed from the University." For similar offences, one of them being, it seems, observance of a Confederateappointed fast day, five or six other students were subjected to suspension from the University family.

The charge of harboring southern sympathies extended even to President Totten and his son, Richard. Though forcing his beliefs on no one, Totten's attitude, Theodore A. Wanrus ${ }^{3}$ reported, brought him the distrust and ill-will of many patriotic persons. "The unfortunate situation was further aggravated when Richard Totten ... who was a student in the University, took part in one of the street demonstrations and from a raised platform, burst forth in fiery denunciation against the North. For this he was pursued by an angry crowd from which he escaped, never to return to Iowa City." Undoubtedly, this incident had much to do with President Totten's resignation on August 19, 1862.

${ }^{3}$ Wanrus was a later student, and historian of the Zetagathian Society. 


\section{Sought Veterans as STUdents}

Following the Civil war, the trustees were eager to have as many soldiers as possible return to the campus as they were mustered out of the armed forces. As an inducement, it was provided that all Iowans who had volunteered in the service of the United States for a period of two or three years, and had received an honorable discharge, could enter any department of the University without paying tuition. The same privilege was extended to those who had enlisted for shorter terms but who had been permanently disabled, or discharged on account of wounds. Fifty-five veterans accepted this provision and enrolled for study in the fall of 1866. Soon, all honorably discharged Iowa soldiers were embraced by this advantage and, eventually, the orphans of such men.

The presence of these veterans brought a new seriousness to the campus. "These were men, not boys," recorded one who saw them. Sobered by years of fighting and hardship, they had learned with deep intensity the worth and need of education. From their "monthly pittance" they had accumulated savings in anticipation of renewing their interrupted academic life. Well experienced in the practice of small economies, they could "prepare their meals and their lessons without the aid of a cook or a pony". It was the judgment of President Pickard that at no time in the history of the institution had so large a proportion of mature men been graduated as between the years 1866 and 1870 .

The University family was most tragically reminded of the cost of war and victory when news was received of the assassination of President Lincoln. Word of the calamity was brought by horseback rider from the nearest telegraph office, at Muscatine, in time to be announced from the pulpits of the city's churches on the morning of Sunday, April 16, 1865. The people of Iowa City, like those of all communities across the land, were grief-stricken. The crime, wrote the editor of the local 
press "draws a pall over the civilization and Christianity of the age, and carries us back to the blood-stained gutters of Paris in the last century; there we look in vain for a parallel. Horrible as are the details of that revolution, we find no case that approaches it. Charlotte Corday was an assassin, but her victim was a murderer. Search among the deeds of the poinard-loving Spaniard, and you return from the hunt with human nature in that age white as snow when contrasted with this exhibition of its depravity in our day and generation." Even the crimes of the Borgias "lose caste and color beside the scarlet hues of our degradation."

John Wilkes Booth, of course, was loathed and execrated. Even his profession was indicted because "the artificial life of the stage appears to have permeated his soul with its falsehoods, and to have prepared him for such deeds as this." The subsidence of the tide of rage was followed by grief's pathetic loneliness bereft of strength and hope. "We have hoped against conviction." wrote the anguished editor", "and now when to hope longer would speak ill for the intelligence ... we can only sit silently down and mourn our afflicted country."

\section{Mourning the President's Demise}

The citizens were called together at the courthouse on Monday, April 17. Ex-Gov. Samuel Kirkwood presided over the meeting assembled "to take some steps in reference to the sad event of the assassination and death of President Lincoln." The decision was arrived at that on the day of the funeral ceremonies at the nation's capital, the people of Iowa City and Johnson county would "turn out in mass and form a funeral procession ... to march to music to the place of public speaking at the State University, the oration to be delivered by Governor Kirkwood."

In sad and solemn mood, the faculty gathered to pass the following resolution:

${ }^{4}$ Probably John P. Irish. 
Abraham Lincoln, President of the United States, having been assassinated on the night of the 14th of April, the faculty resolved that as teachers and students we would unite with the citizens of this city in the celebration of his funeral obsequies, on this day.

And that we may, in a becoming manner, give expression to our sorrow for the calamity which has befallen us as a people, and also our detestation of the crime by which he was so suddenly stricken down in the prime of life, and in the zenith of his career. It was agreed

1st-That the usual exercises of the University be dispensed with during the entire day

2nd-That the capitol building be draped in mourning

3rd-That the teachers and students be assembled at 12 o'clock $\mathrm{M}$ and formed into a procession to take its appropriate place in the general procession of the citizens

4th-That the faculty and students be provided with suitable black and white rosettes, to be worn in procession.

On the appointed day, the anniversary of the far-away battle of Lexington and Concord, the mournful plans were carried out. A contemporary photograph shows the windows of the east front of the Old Capitol draped with the black cloth of mourning, and the officials massed on the steps and portico facing the students, veterans, bandsmen, and other assembled citizens. The pioneering newness of the scene is well observed in the surrounding brush and freshly-planted trees; the grass plot heavily rutted with wagon wheels, and the crude rail fence, recently erected to enclose the campus against traffic and livestock.

Ex-Gov. Kirkwood carried out his assignment. The martyred President, he said, was beloved of the nation for his preeminent purity of purpose, his devotion to the public good, his clearness of judgment, firmness of will, and kindness of heart. "We mourn him not only as the good magistrate and the good man but as the good friend, for there was not in all our broad land a man so humble that he was not his friend, unless that man was the enemy of his country." 
The oration traced the events in the life of Lincoln that had advanced him from the log cabin of his birth in Kentucky to the White House in the nation's capital city. The speaker dwelt lovingly on the merits and virtues of the lost leader, and bitterly assailed "the crime, so foul and brutal," that brought him to his death. He closed with the prayer and prediction that "When the strife and bitterness of the day shall have passed away with those who participated in that strife and felt that bitterness; when the impartial historian shall have written the history of this fearful struggle, our children's children will learn to love the name and the memory of Lincoln as we have learned to love the name of Washington."

\section{THE HIGH AIMS OF GOVERNMENT}

Gov. James W. Grimes: Here the population is drawn from all parts of the civilized globe, where the public policy and public institutions are just being established, and where different portions of the state are in different conditions of progress and development. It is a difficult task to protect and advance the pioneer interests of our western settlements, and also encourage and establish on a substantial basis, the commercial and manufacturing interests of the old counties, by general laws that shall operate equally and beneficently upon all.

It is not an easy matter to lay strong and deep foundations of the educational institutions of a new state, and to rear thereon superstructures that shall honor the state and bless mankind. The duty of restoring reason to those who are bereft of it, of giving sight to the blind and hearing to the deaf, by the establishment and proper endowment of charitable institutions; of repressing evil; of punishing crime; of stimulating industry; of protecting public virtue, and of maintaining the integrity of the state sovereignty, cannot be exercised without incurring grave responsibilities. 
Government is established for the protection of the governed. But that protection does not consist merely in the enforcement of laws against injury to the person and property. Men do not make a voluntary abnegation of their natural rights, simply that those rights may be protected by the body politic. It reaches more vital interests than those of property. Its greatest object is to elevate and ennoble the citizen. It would fall far short of its design if it did not disseminate intelligence and build up the moral energies of the people. It is organized "to establish justice, promote the public welfare and secure the blessings of liberty." It is designed to foster the instincts of truth, justice and philanthropy, that are implanted in our very natures, and from which all constitutions and all laws derive their validity and value. It should afford moral as well as physical protection, by educating the rising generation; by encouraging industry and sobriety; by steadfastly adhering to the right, and by being ever true to the instincts of freedom and humanity.

And to accomplish these high aims of government, the first requisite is ample provision for the education of the youth of the state. The common school fund of the state should be scrupulously preserved, and a more efficient system of common schools than we now have should be adopted. The state should see to it that the elements of education, like the elements of universal nature, are above, around, and beneath all. It is agreed that the safety and perpetuity of our republican institutions depends of the diffusion of intelligence among the masses of the people ... Education is the great equalizer of human conditions. It places the poor on an equality with the rich. It subjects the appetites and passions of the rich to the restraints of reason and conscience, and thus prepares each for a career of usefulness and honor. Every consideration, therefore, of duty and policy, impels us to sustain the common schools of the state in the highest possible efficiency.- Inaugural address to the Fifth General Assembly, December 9, 1854. 
Copyright of Annals of Iowa is the property of State of Iowa, by \& through the State Historical Society of Iowa and its content may not be copied or emailed to multiple sites or posted to a listserv without the copyright holder's express written permission. However, users may print, download, or email articles for individual use. 